\title{
Morphometric Analysis of a semi-arid region using GIS
}

\author{
Rohit Kumar Arya ${ }^{1}$ and Virender Kumar Sarda ${ }^{2}$
}

\begin{abstract}
In the present study an attempt has been made to study the morphometric parameters and drainage properties of a watershed of semi-arid (khad) region located at Hoshiarpur district of Punjab (India). Morphometric analysis has been carried out on the watershed of $174.385 \mathrm{~km}^{2}$ area using ESRI Arc GIS 10.0 software and CartoSAT-1 DEM data of spatial resolution 2.5 m obtained from NRSC (National Remote Sensing Center), Hyderabad for evaluating various morphometric parameters. On the basis of linear, areal and relief aspects various morphometric parameters were evaluated using Arc GIS 10.0 software. Hydrology tool under Spatial analyst tool in ArcGIS10.0 has been used for generating the watershed boundary, flow accumulation, drainage network and stream order map. Area and the perimeter have been calculated using ArcGIS 10.0 and it comes out to be 174.385 $\mathrm{Km}^{2}$ and $77.539 \mathrm{~km}$ respectively. Drainage map of the study area shows dendritic to sub-dendritic drainage pattern. The study reveals that the stream number decreases with the increase in the stream order, the mean bifurcation ratio of the watershed is 4.35 which means that the watershed falls under normal basin category, the elongation ratio of the watershed is 0.604 which indicates that it is less elongated, the circularity ratio of the watershed is 0.365 indicating its elongation and highly permeable homogeneous materials. The present study shows the competency of remotely sensed satellite imagery coupled with GIS for morphometric analysis of a particular region and is useful for the watershed management, identification of critical zones and for implementing various soil and water conservation practices in that region or watershed.
\end{abstract}

Keywords: Morphometric Parameters; DEM; CartoSAT-1; ArcGIS10.0; Remote Sensing.

\section{INTRODUCTION}

Geomorphology is defined as the scientific study of landforms. Geo means 'earth', Morpho means 'form' and Logy means 'discourse' or 'science'. It is a branch of Earth Science, which has grown after the advent of Aerial photographs and satellite data. Geomorphology, along with information on soil, water and vegetation has become one of the essential inputs in planning for various developmental activities. The scope of geomorphology has further expanded with the landform maps widely used in various fields of resource surveys, environmental analysis, hydrological studies, engineering applications and geo-technical studies. As a result, experts in various fields such as geoscience, pedology, hydrology, civil engineering, urban planning, etc. have started intuitively using landform maps for various applications in their respective fields. Morphometry is the measurement and mathematical analysis of the configuration of the earth's surface, shape and dimension of its landforms (Clarke, 1966), while, morphometric analysis of a watershed provides a quantitative description of the drainage system, which is an important aspect of the characterization of watersheds (Strahler, 1964). The morphometric analysis for individual sub basins is achieved through measurements of linear, aerial and relief aspect of the basin and slope contribution (Nag and Chakraborthy, 2003). The satellite Remote Sensing has the ability to provide a synoptic view of a large area and is very useful in analyzing drainage morphometry. The image interpretation techniques are less time consuming than the ground surveys, which if coupled with limited field checks, yield valuable results. Many researchers like Srivastava (1997), Nag (1998), Nag and Chakraborty (2003), Srinivasa (2004), Vittala et al. (2004), Nongkynrih and Hussain (2011), Pareta and Pareta (2012), Ravikumar and Madesh (2012), Ali and Khan (2013), Aravinda and Balakrishna (2013), Yasmin et al. (2013) etc. have carried out morphometric analysis using Remote Sensing techniques. In the present study, Remote sensing data has been used in GIS platform to have the morphometric study of a watershed of semi-arid (khad) region located in Hoshiarpur district of Punjab (India). This study will be useful for the watershed management, identefication of critical zones and for implementing various soil and water conservation practices in this watershed.

\section{STUDY AREA}

The study area lies in a semi- arid region of Hoshiarpur district located between $75^{\circ} 50^{\prime} 54.14 " \mathrm{E}$ and $76^{\circ} 05^{\prime} 22.12^{\prime \prime} \mathrm{E}$ longitude, $31^{0} 31^{\prime} 02.04 " \mathrm{~N}$ and $31^{0} 32^{\prime} 22.12^{\prime \prime} \mathrm{N}$ latitude. It covers some part of Una district in Himachal Pradesh. Survey of India toposheets number H43D14 and H43E2 provides the topographic coverage of the study area. The outlet point $\left(31^{0} 32^{\prime} 59.493 " \mathrm{~N}\right.$ latitude and $75^{\circ} 50^{\prime} 52.922^{\prime \prime} \mathrm{E}$ 
longitude) of the watershed is selected on a khad located near Hargarh village, Hoshiarpur (Punjab). The study area covers the area of 174.385 sq.km including places like Hardo Khanpur, Bassi Nau, Bassi Ballo, Khakhli, Brahmjit, Akhlaspur, Sarin, Saleran, Thathal, Sherpur, Dada, Chohal, Manjhi,
Mustafapur, Arniala Shahpur, Baroti, Naria, Kakon, Ajjowal, Sukhdev Nagar, Kotli Gounspur, Kotla Jhiri etc. of Hoshiarpur district, Punjab. Figure 1describes the location of the study area and Figure 2 represents the base map of the study area.

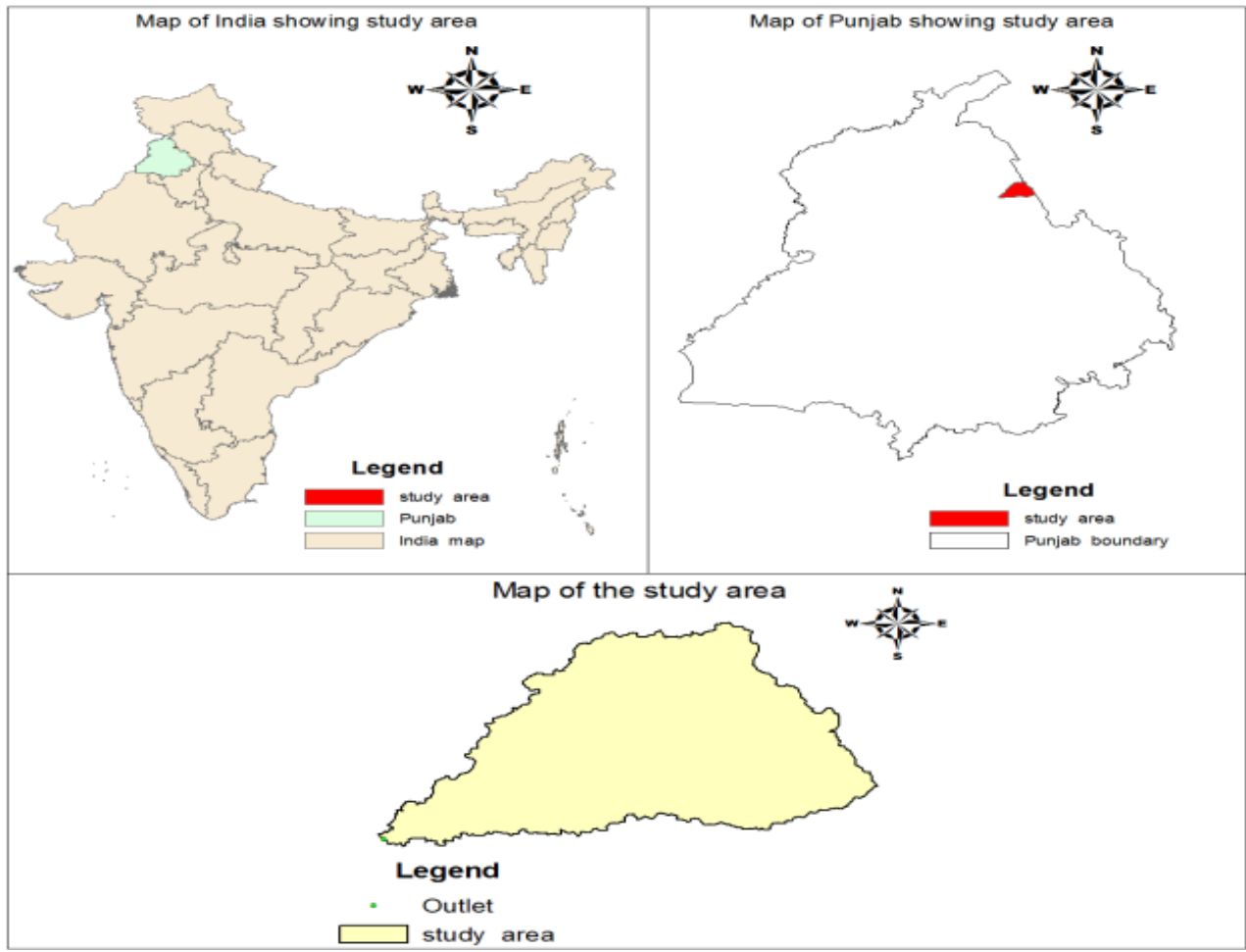

Figure 1 Description about the Study Area

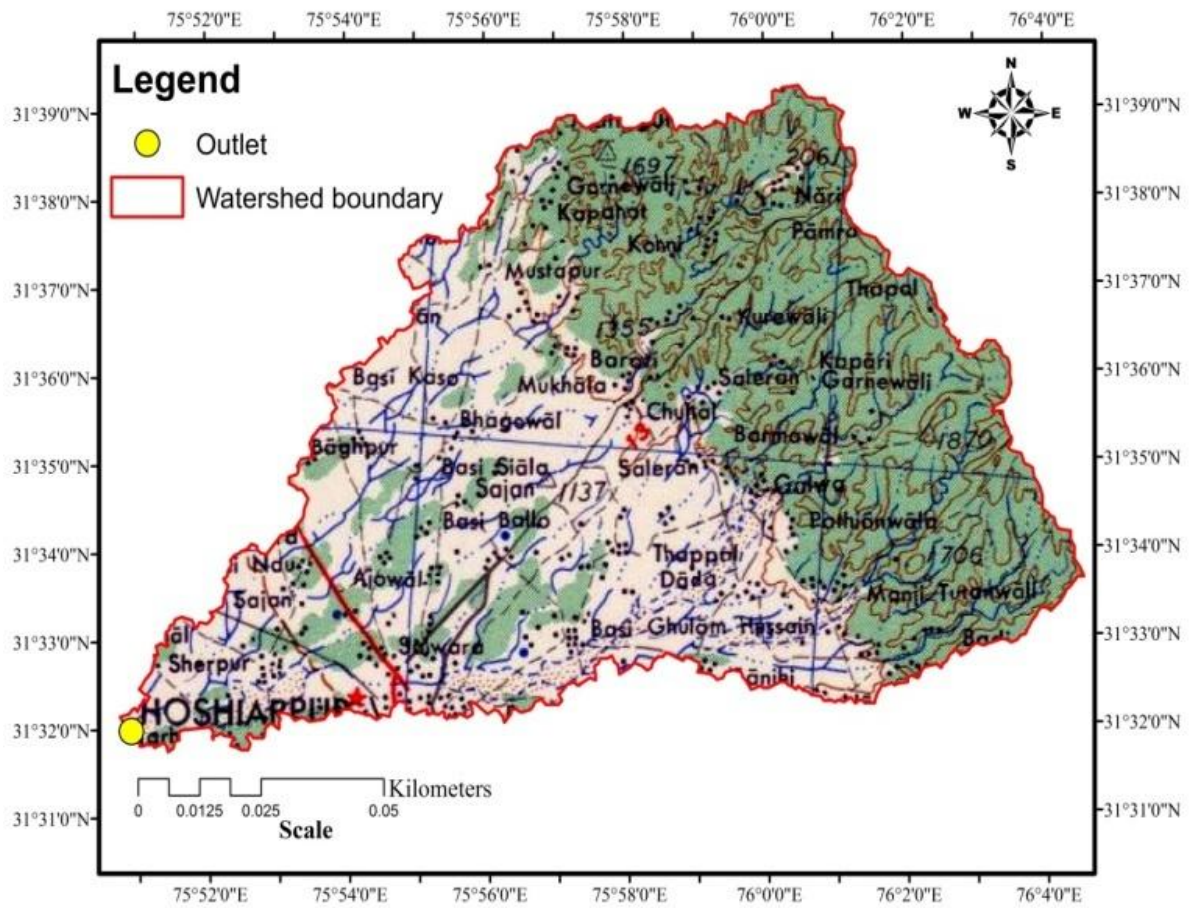

Figure 2 Base Map of the study area 


\section{DATA AND METHODOLOGY}

Remotely sensed satellite imagery data were processed using Spatial Analyst Tool in Arc GIS 10.0 software for preparing various maps and morphometric parameters were then evaluated for studying the drainage characteristics of the watershed. Description of methodology adopted in the present study is expressed in Figure 3.

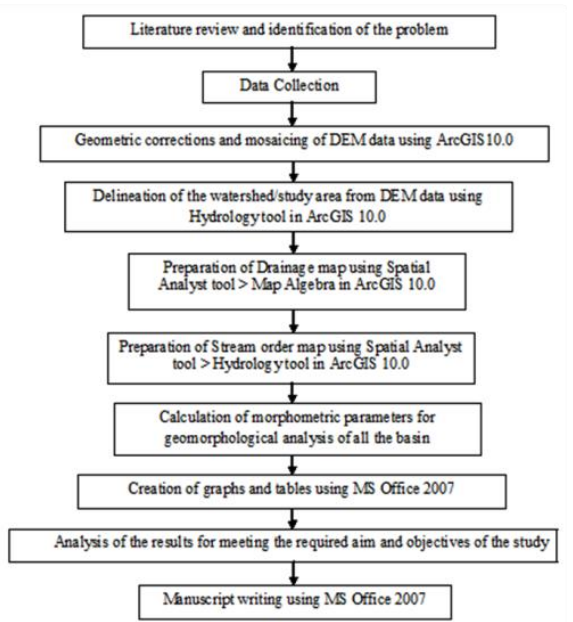

\subsection{Data Collection}

In order to carry out the present study, the required data were collected from various agencies detailed below:

\subsubsection{Toposheets of the area}

The study area falls under SOI toposheets number H43D14 and H43E2 which were taken as reference for geometric corrections, area and perimeter calculations of the study area in 1:50,000 scale, obtained from Survey of India office, Chandigarh.

\subsubsection{Satellite Imagery data}

CartoSAT-1 DEM satellite imagery data with $2.5 \mathrm{~m}$ spatial resolution was used in the present study and was obtained from NRSC, Hyderabad. DEM data show the elevation (meters) in grids of different points of a particular region (Figure 4). All the above data was analysed using ERDAS Imagine 9.1, ESRI ArcGIS 10.0 software with Spatial Analyst tool.

Figure 3 Methodology adopted in the present study

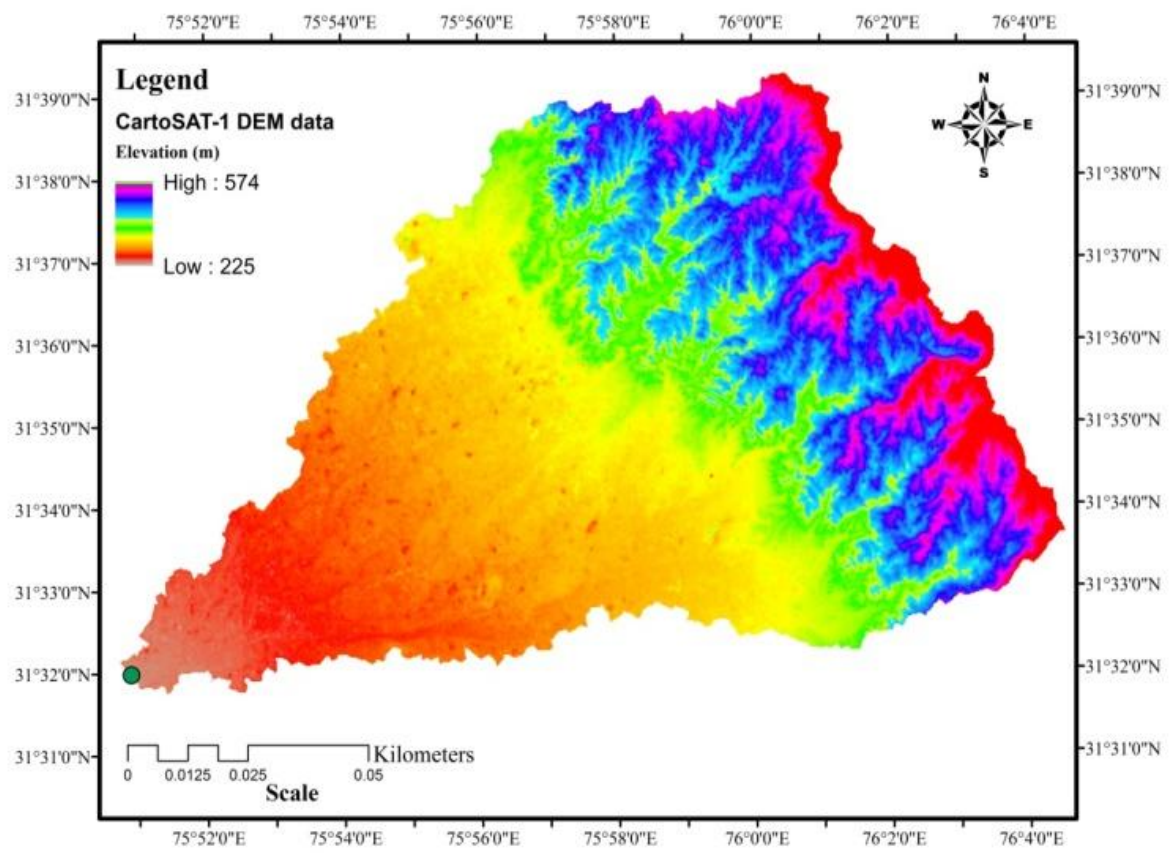

Figure 4 CartoSAT-1 DEM (2.5m spatial resolution) data of the study area

\subsection{Flow accumulation map}

Flow accumulation map of the study area was obtained from CartoSAT-1 DEM data using Spatial Analyst tool > Hydrology tool in ArcGIS 10.0 software. It shows the raster of accumulated flow in each cells (Figure 5) where high values of flow is represented in white cells and low values were represented in black cells. 


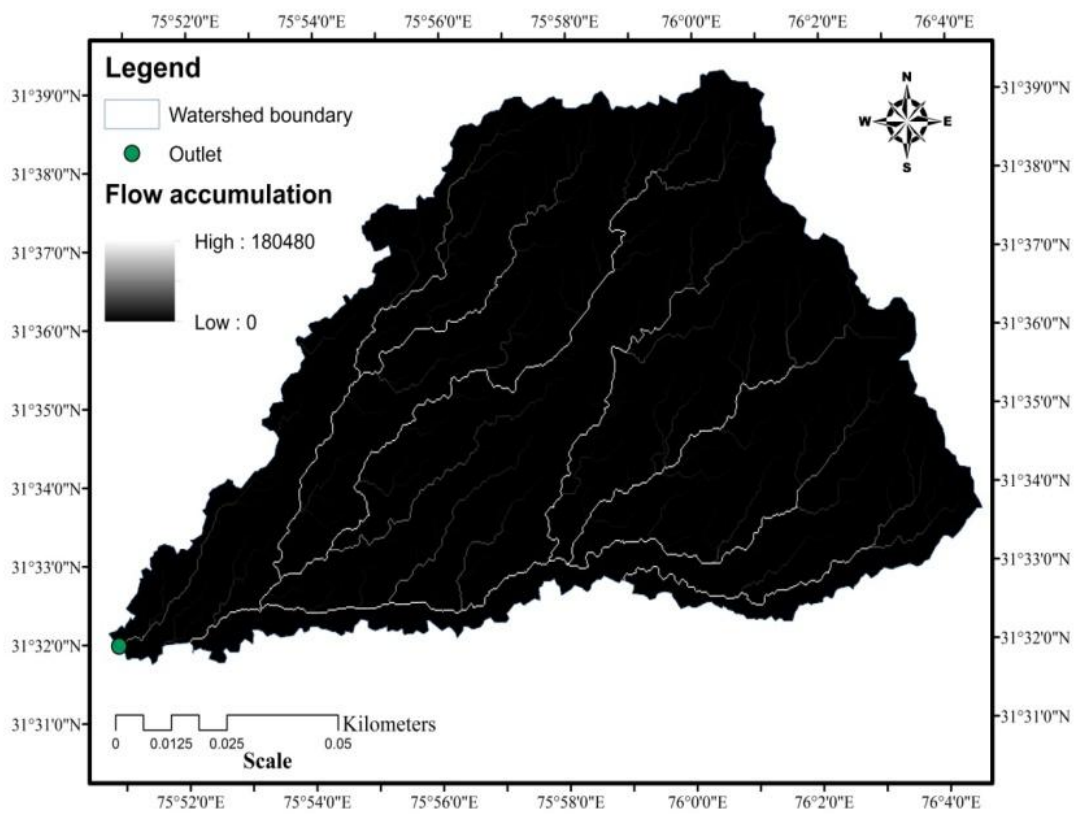

Figure 5 Flow Accumulation map

\subsection{Drainage network map}

Drainage network map of the study area was obtained from CartoSAT-1 DEM data using Spatial Analyst tool > Map Algebra > Raster Calculator in ArcGIS 10.0 software. It shows the raster of drainage network of the study area in each cells (Figure 6) where drainage lines were represented in black cells. Drainage network of the study area shows dendritic to sub-dendritic drainage pattern.

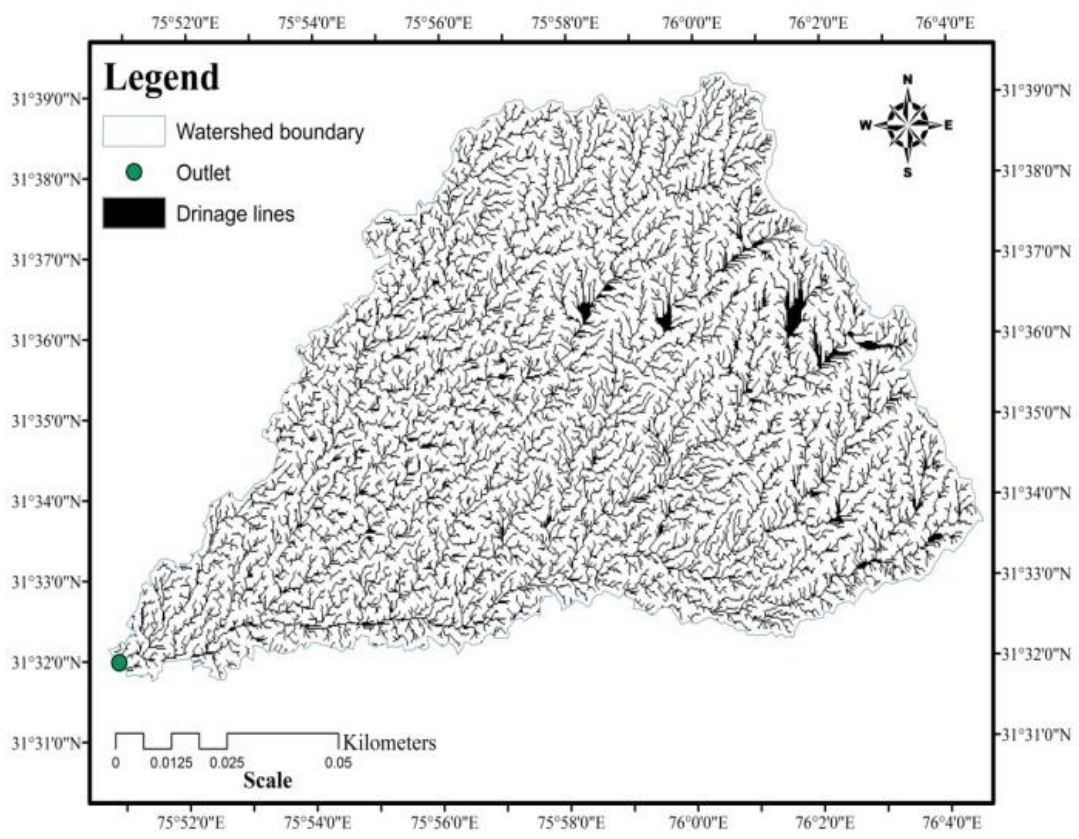

Figure 6 Drainage network map of the study area

\subsection{Contour map}

Contour map of the study area was prepared from CartoSAT-1 DEM data using Surface tool under
Spatial Analyst tools and it represents the contours having different elevations in the study area (Figure 7). 


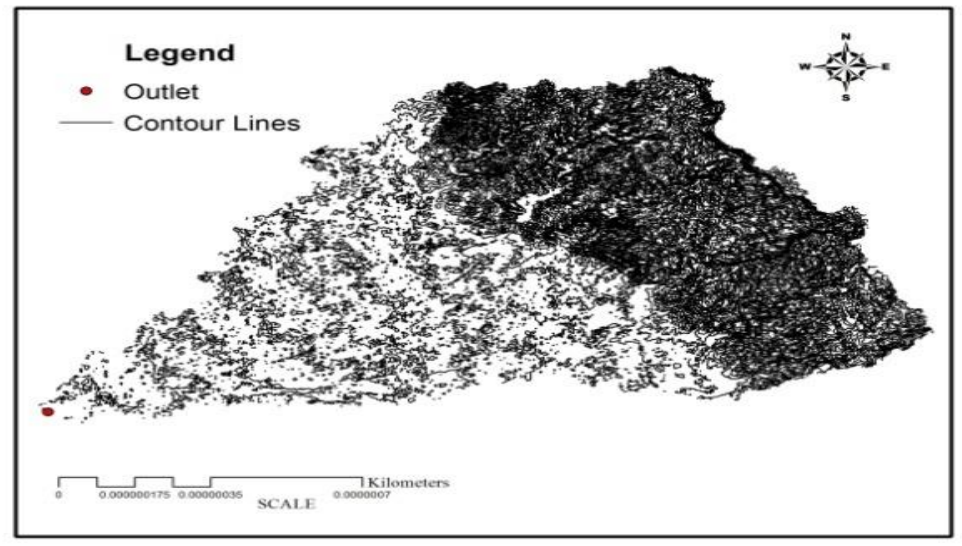

Figure 7 Contour map of the study area

\section{RESULTS AND DISCUSSION}

In the present study 26 morphometric parameters were evaluated for identifying various characteristics of the watershed. Area of the watershed, its perimeter, various maps were obtained using Arc GIS 10.0 software. Stream order is calculated using Strahler's method (1964) using Hydrology tool in ArcGIS10.0 and other parameters viz. stream number, stream length, bifurcation ratio, elongation ratio, form factor, circularity ratio etc. were calculated using mathematical formulas. Morphometric parameters have been classified into three aspects of the basin slope: Linear Aspects, Areal Aspects, Relief Aspects

\subsection{Linear Aspects}

Linear aspects include morphometric parameters viz. Stream order (u), Stream number $\left(\mathrm{N}_{\mathrm{u}}\right)$, Stream length $\left(\mathrm{L}_{\mathrm{u}}\right)$, Mean stream length $\left(\mathrm{L}_{\mathrm{um}}\right)$,
Stream length ratio $\left(\mathrm{L}_{\mathrm{urm}}\right)$, Bifurcation ratio $\left(\mathrm{R}_{\mathrm{b}}\right)$, Mean bifurcation ratio $\left(\mathrm{R}_{\mathrm{bm}}\right)$ and Basin length $\left(\mathrm{L}_{\mathrm{b}}\right)$ which are calculated in the present study.

\subsubsection{Stream Order (u)}

Stream order (u) expresses the hierarchal relationship between the individual stream segments that make up a drainage network. Stream ordering is the first step in morphometric analysis of the watershed. The stream ordering systems was first advocated by Horton (1945) which was later modified by Strahler (1952). In the present study Strahler's method is used in Arc GIS 10.0 for determining the stream order. It has been observed from the result that the frequency of stream decreases as the stream order increases and the maximum frequency lies in the case of first order streams. Result also shows that the order of the watershed is of seventh order. Figure 8 shows the stream order map of the study area.

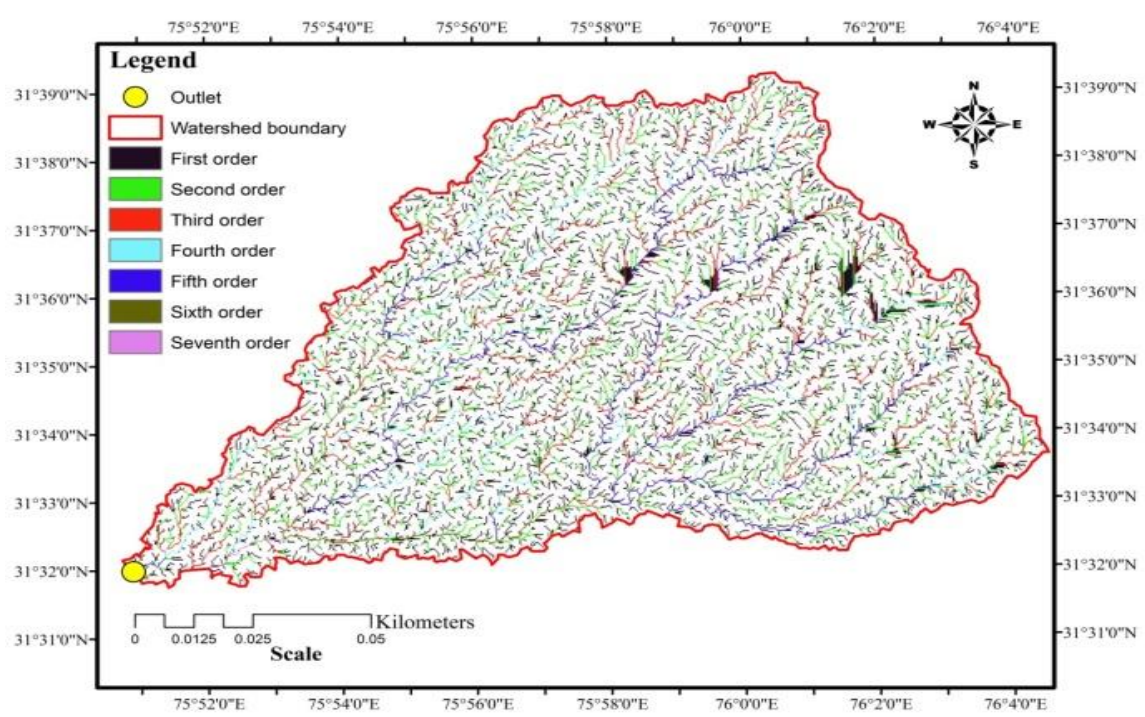

Figure 8 Stream order map of the study area 


\subsubsection{Stream Number $\left(\mathrm{N}_{\mathrm{u}}\right)$}

The total number of stream segments present in each order is the stream number $\left(\mathrm{N}_{\mathrm{u}}\right)$. $\mathrm{N}_{\mathrm{u}}$ is number of streams of order u. According to Horton (1945) the numbers of stream segments of each order form an inverse geometric sequence with order number. In the present study stream number $\left(\mathrm{N}_{\mathrm{u}}\right)$ supports Horton's law i.e. stream number decrease with increase in stream order in this basin. Figure 9 shows the variation of stream number with respect to the stream order.

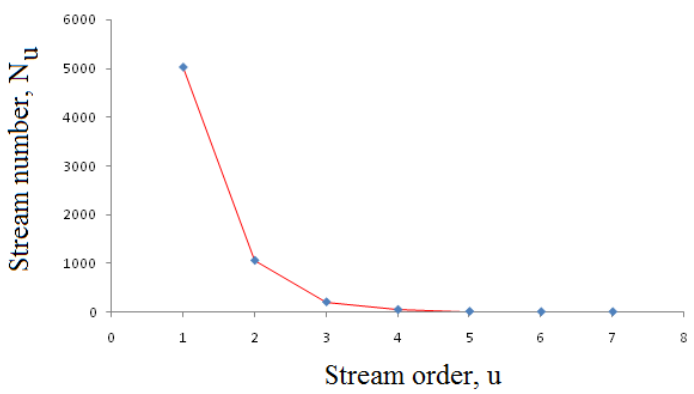

Figure 9 Variation of Stream Number with Stream Order

\subsubsection{Stream Length $\left(L_{u}\right)$}

Stream length of a stream order is the total length of all the streams in that orders. Horton's law of stream lengths supports the theory that geometrical similarity is preserved generally in watershed of increasing order, Strahler (1964).

In the present study, stream length decreases exponentially with increasing stream order. Figure 10 shows the variation of stream length with respect to the stream order.

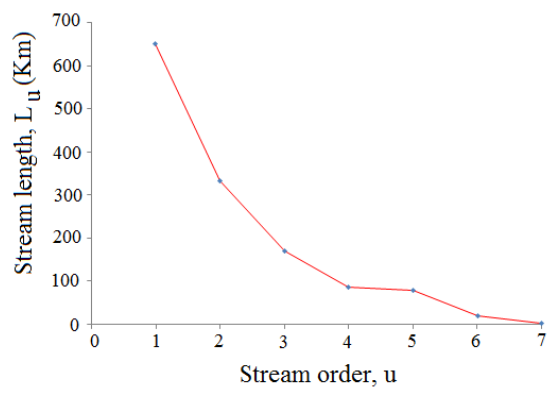

Figure 10 Variation of Stream Length with Stream Order

\subsubsection{Mean Stream Length $\left(L_{u m}\right)$}

The mean stream length is a dimensionless property, characterizing the size aspects of drainage network and its associated surface (Strahler, 1964). It is obtained by dividing the total length of stream of an order by total number of segments in the order. Mean stream length of the study area reveals a increasing trend with the increase in stream order and then again decreasing after fourth stream order Figure 11.

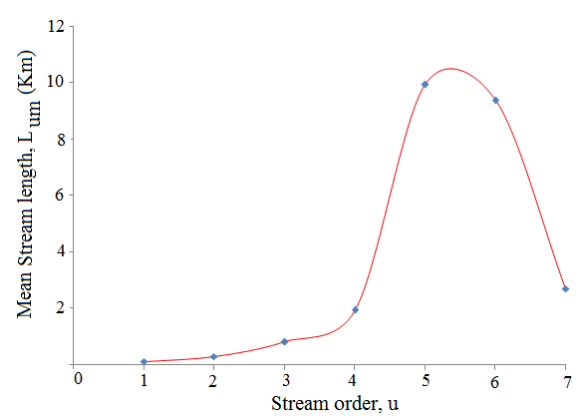

Figure 11 Variation of Mean Stream Length with Stream Order

\subsubsection{Stream Length Ratio $\left(L_{u r}\right)$}

states that the length ratio is the ratio of the mean $\left(\mathrm{L}_{\mathrm{u}}\right)$ of segments of order $(\mathrm{u})$ to mean length of segments of the next lower order $\left(\mathrm{L}_{\mathrm{u}}-1\right)$, which tends to be constant throughout the successive orders of a basin (Horton, 1945). This law also states that the mean length of stream segments of each of the successive orders of a basin tends to approximate a direct geometric series, with stream lengths increasing towards higher stream order. Change of stream length ratio from one order to another order indicates their late youth stage of geomorphic development (Singh and Singh, 1997). The stream length ratio of the study area has been found to ranges from 0.196 to 3.464 . The variation in the stream length ratio of streams of different orders may be due to variation in slope and topography of the basin.

\subsubsection{Bifurcation Ratio $\left(\mathbf{R}_{\mathrm{b}}\right)$}

The bifurcation ratio is the ratio between the numbers of streams in one order $(\mathrm{Nu})$ to the next higher order $\left(\mathrm{N}_{\mathrm{u}}+1\right)$. Horton (1945) considered the bifurcation ratio as index of relief and dissertation. Strahler (1957) demonstrated that bifurcation ratio shows a small range of variation for different regions or for different environment except where the powerful geological control dominates. It is observed from the $R_{b}$ is not same from one order to its next order. These irregularities are dependent upon the geological and lithological development of the drainage basin (Strahler, 1964). The lower values of $R_{b}$ are characteristics of the watersheds, which have suffered less structural disturbances (Strahler, 1964) and the drainage pattern has not been distorted because of the structural disturbances (Nag, 1998). Whereas, higher bifurcation ratio results in large variation of frequencies between successive orders and indicates a mature topography (Sreedevi et al., 2004). In the present study the bifurcation ratio has been found to ranges from 2 to 5.5 indicating large variation in frequencies between successive orders and a mature topography, while the lower values 
indicates the areas which are not affected by structural disturbances.

\subsubsection{Mean Bifurcation Ratio $\left(\mathbf{R}_{\mathrm{bm}}\right)$}

Mean Bifurcation Ratio is arithmetic mean of bifurcation ratios of all orders. In the present study the mean bifurcation ratio has been found to 4.35 which means that the watershed falls under normal basin category (Strahler, 1957).

\subsubsection{Basin Length $\left(L_{b}\right)$}

Schumm (1956) defined the basin length as the longest dimension of the basin parallel to the principal drainage line. Gregory and Walling (1968) defined the basin length as the longest in the basin in which are end being the mouth. Gardiner (1975) defined the basin length as the length of the line from a basin mouth to a point on the perimeter equidistant from the basin mouth in either direction around the perimeter. In the present study basin length is determined by the definition of Schumm (1956) and it comes out to be $24.61 \mathrm{Km}$..

\subsection{Areal Aspects}

Various areal aspects that have been determined in the present study are discussed below.

\subsubsection{Drainage Density (D)}

Drainage density is the ratio of the total length of all the streams in the basin to the area of the watershed (Horton, 1945; Strahler, 1952 and Melton, 1958). Low drainage density means permeable subsoil material, dense vegetation, low relief and coarse drainage texture. High drainage density is the resultant of weak or impermeable subsurface material, sparse vegetation, mountainous relief and fine drainage texture $[\mathrm{Nag}$, 1988]. In the present study the drainage density is calculated by the method proposed by Horton (1932) and has been found to be equal to 7.68 which indicates moderate drainage density, that means the basin is moderate permeable sub-soil and thick vegetative cover.

\subsubsection{Drainage Texture $\left(D_{t}\right)$}

Drainage texture is one of the important concepts of geomorphology and is defined as the total number of stream segments of all order in a basin divided by the perimeter of the basin. It indicates the relative spacing of drainage lines. Drainage texture depends on lithology, infiltration capacity and relief aspect of the terrain. It is total number of stream segments of all orders per perimeter of that area [Horton, 1945]. Smith (1939) has classified drainage texture into five different textures i.e., very coarse $(<2)$, coarse $(2$ to 4$)$, moderate (4 to 6), fine (6 to 8 ) and very fine (>8). The drainage texture of the study area has been found to be 81.76 and falls under very fine drainage texture category.

\subsubsection{Elongation Ratio $\left(R_{\mathrm{e}}\right)$}

Elongation Ratio (Re) indicates the shape of the basin. Schumm (1956) defined elongation ratio as the ratio of diameter of a circle of the same area as the basin to the maximum basin length. According to Strahler this ratio runs between 0.6 and 1.0 over a wide variety of climatic and geologic types. The varying shapes of watershed can be classified with the help of the index of elongation ratio, i.e. circular $(0.9-0.10)$, oval $(0.8-0.9)$, less elongated (0.7-0.8), elongated (0.5-0.7), and more elongated (less than 0.5 ). The elongation ratio of the study area is determined by the method proposed by Schumm (1956) and it has been found to be 0.604 which means the watershed comes under elongated category.

\subsubsection{Circularity Ratio $\left(\mathbf{R}_{\mathrm{c}}\right)$}

Circularity ratio is defined as the ratio of the area of the basin to the area of a circle having the same circumference as the perimeter of the basin. Miller and Summerson (1960), has described the basin of the circularity ratios range 0.4 to 0.7 , which indicates strongly elongated and highly permeable homogenous geologic materials. The circularity ratio of the study area was found to be equal to 0.37 and it does not comes under the above range indicating its less strong elongated shape and near to highly permeable homogenous geologic materials.

\subsubsection{Form Factor Ratio $\left(R_{\mathrm{f}}\right)$}

It is a dimensionless property and is used as a quantitative expression of the shape of basin form. Horton (1945) defined form factor as the ratio of basin area to square of the basin length. The value of form factor would always be less than for a perfectly circular watershed $=0.754$. Smaller the value of form factor, more elongated will be the watershed. Watershed circular in shape have high peak flows of shorter duration, whereas the watershed which are elongated in shape have low peak flow for longer durations. In the present study, the form factor has been found to be 0.286 indicating elongated shape, less peak flow for longer duration and less runoff in the study area.

\subsubsection{Stream Frequency $\left(F_{s}\right)$}

Stream frequency is the ratio of total number of stream segments of all orders to the basin area (Horton, 1945). Stream frequency of the watershed has been found to be 36.351 which indicate increase in stream population with respect to the drainage density of the basin. 


\subsubsection{Infiltration Number $\left(I_{f}\right)$}

The infiltration number is defined as the product of drainage density (D) and stream frequency (Fs).It gives us an idea about the infiltration characteristics of the watershed .In the present study infiltration number is determined by the method proposed by Faniran (1968) and it comes out to be 279.176 indicating high infiltration rate and low runoff in the watershed.

\subsubsection{Length of Overland Flow $\left(\mathrm{L}_{\mathrm{g}}\right)$}

The term is used to describe the length of flow of water over the ground before it becomes concentrated in definite stream channels. Horton (1945) used this term to refer to the length of the run of the rainwater on the ground surface before it is localized into definite channels and expressed it as equal to half of the reciprocal of drainage density (D). In the present study length of overland flow comes out to be equal to $0.065 \mathrm{Km}$ which shows its low surface runoff and is almost half of the constant of channel maintenance.

\subsubsection{Constant of Channel Maintenance (C)}

This parameter indicates the requirement of the units of watershed surface to bear one unit of channel length. Schumm (1956) has defined it as the inverse of the drainage density and having the dimension of length. The constant of channel maintenance of the study area has been found to be 0.1302 indicating its low structural disturbances, high permeability, less steep slopes and low surface run off.

\subsubsection{Compactness Coefficient $\left(\mathrm{C}_{\mathrm{c}}\right)$}

Gravelius (1914) defined compactness coefficient of a watershed as the ratio of perimeter of watershed to circumference of circular area equals to the area of the watershed. The compactness coefficient is independent of size of watershed and is dependent only on the slope. Compactness coefficient of the watershed has been found to be 1.668 using Gravelius(1914) approach.

\subsubsection{Shape Factor Ratio $\left(R_{s}\right)$}

It defines the shape of the watershed. Horton (1932) had given the formula for finding the shape factor ratio which has been used in the present study. The shape factor ratio of the watershed has been found to be 3.498 indicating its elongated shape.

\subsection{Relief Aspects}

\subsubsection{Height of basin mouth $(\mathrm{z})$}

Height of the basin mouth is the lowest point of elevation on the watershed or the outlet of the watershed. It is determined in Arc GIS 10.0 software and has been found to be $225 \mathrm{~m}$.

\subsubsection{Maximum height of the basin $(\mathrm{Z})$}

Maximum height of the basin is the highest point of elevation on the watershed. It is determined in Arc GIS 10.0 software and comes out to be $574 \mathrm{~m}$.

\subsubsection{Total basin relief $(\mathbf{H})$}

Difference in the elevation between the highest point of a watershed and the lowest point on the valley floor is known as the total relief of the river basin. The total basin relief of the watershed is $349 \mathrm{~m}$.

\subsubsection{Relief Ratio $\left(\mathbf{R}_{\mathrm{hl}}\right)$}

The relief ratio may be defined as the ratio between the total relief of a basin and the longest dimension of the basin parallel to the main drainage line (Schumm, 1956). The possibility of a close correlation between relief ratio and hydrologic characteristics of a basin has been suggested by Schumm(1956) who found that sediments loss per unit area is closely correlated with relief ratios. In the present study, the value of relief ratio has been found to be 14.18. It has been observed that areas with low to moderate relief and slope are characterized by moderate value of relief ratios. Low value of relief ratios are mainly due to the resistant basement rocks of the basin and low degree of slope.

\subsubsection{Ruggedness Number $\left(R_{n}\right)$}

Strahler (1968) defined ruggedness number is the product of the basin relief and the drainage density and usefully combines slope steepness with its length. Calculated accordingly, the watershed has a ruggedness number has been found to be 2.6803. The low ruggedness value of watershed implies that area is less prone to soil erosion and have intrinsic structural complexity in association with relief and drainage density.

\section{CONCLUSION}

Quantitative geomorphologic analysis of the watershed in a semi - arid region provides us detailed information about the various characteristics of the watershed. Table 1 and Table 2 gives a detailed description of the morphometric parameters evaluated in the present study. The detailed study of morphometric parameters shows that the watershed is of seventh order. The watershed is elongated with circulatory ratio of 0.365 and elongation ratio is 0.604 . The drainage texture of the watershed is very fine and its drainage density shows its areas of moderate permeable subsoil material, thick vegetation and low relief. The high infiltration number shows its low surface runoff. The mean bifurcation ratio of the watershed is 4.35 which show that it falls under normal basin category and in which geologic structures do not distort the drainage pattern. The 
ruggedness number shows that the area is low to moderateely prone to soil erosion due to surface runoff. Drainage density $\left(D_{d}\right)$ value implies that the study area has moderate permeable sub-soil and thick vegetative cover.

The study reveals that remote sensing data used with GIS is a compatible and powerful tool for evaluation of various morphometric parameters and its influence on landforms. GIS facilitates analysis of various morphometric parameters and acts as an effective tool in establishing relationship between drainage morphometry and properties of landforms. The present study is also useful for providing information and proper guidance for watershed management, rainwater harvesting and several other development processes in a watershed.

\section{REFERENCES}

[1]. Biswas, S., Sudhakar, S., and Desai, V.R (1999), Prioritization of sub-watersheds based on Morphometric Analysis of Drainage Basin: A Remote Sensing and GIS Approach. Journal of the Indian Society of Remote Sensing, 27(3), pp. 155-166.

[2]. Clarke, J.I. (1996). Morphometry from Maps. Essays in Geomorphology. Elsevier publication. Co. New York, pp.235-274.

[3]. Faniran, A. (1968). The index of drainage intensity - A provisional new drainage factor. Australian Journal of Science, 31, pp. 328-330.

[4]. Gardiner, V. (1975). Drainage basin morphometry. British Geomorphological Group, Technical Bulletin, 14,pp. 48.

[5]. Gregory, K.J., and Walling, D.E. (1968). The variation of drainage density within a catchment. International Association of Scientific Hydrology - Bulletin, 13, pp. 6168.

[6]. Gravelius, H. (1914). Flusskunde. Goschen'sche Verlagshandlung, Berlin.

[7]. Horton, R.E. (1932). Drainage basin characteristics. Transactions American Geophysical Union, 13, pp. 350-61.

[8]. Horton, R.E (1945), Erosional development of streams and their drainage basins; Hydrophysical Approach to Quantitative Morphology. Geol. Soc. Am. Bull., 56, pp. 275-370.

[9]. Khan, M.A., Gupta, V.P. and Moharana, P.C (2001). Watershed prioritization using remote sensing and geographical information system: a case study from Guhiya(India). Journal of Arid Environments, 49, pp. 465475.

[10]. Melton, M.A. (1958). Geometric properties of mature drainage systems and their representation in E4 Phase Space. Journal of Geology, 66, pp. 35-54.

[11]. Miller, O.M. and Summerson, C.H. (1960). Slope zone maps. Geographical Review, 50, pp. 194-202.

[12]. Nag, S.K. (1998). Morphometric analysis using remote sensing techniques in the Chaka sub-basin, Purulia district, West Bengal. Journal of Indian Society of Remote Sensing, 26 (1), pp. 69-76.

[13]. Nag, S.K. and Chakraborthy, S. (2003). Influence of rock types and structures in the development of Drainage Network in Hard Rock Area. J. Indian Soc. Remote Sensing, 31(1), pp. 25-35.

[14]. Schumm, S.A. (1956). Evolution of drainage systems and slopes in Badlands at Perth Anboy, New Jersey. Bulletin of the Geological Society of America, 67, pp. 597646.

[15]. Singh, N. (1990). Geomorphology of Himalayan rivers (a case study of Tawi basin), Jay Kay Book House, Jammu Tawi.

[16]. Singh, S., and Singh, M.C. (1997). Morphometric analysis of Kanhar river basin. National Geographical Journal of lndia, 43(1), pp. 31-43.

[17]. Smith, G.H. (1939). The morphometry of Ohio: The average slope of the land (abstract). Annals of the Association of American Geographers, 29, pp. 94.

[18]. Sreedevi, P.D., Owais, S., Khan, H.H. and Ahmed, S. (2009) Morphometric Analysis of a Watershed of South India Using SRTM Data and GIS. Journal Geological Society of India Vol.73, April 2009, pp. 543-552.

[19]. Sreedevi, P.D., Subrahmanyam, K. and Ahmed, S. (2004) The Significance of Morphometric Analysis for Obtaining Groundwater Potential Zones in a Structurally Controlled Terrain. Environmental Geology, Vol. 47, No. 3, 2004, pp. 412-420.

[20]. Strahler, A.N. (1952).Dynamic basis of geomorphology.Bulletin of the Geological Society of America, 63, pp. 923-938.

[21]. Strahler, A.N. (1957). Quantitative analysis of watershed geomorphology. Transactions American Geophysical Union, 38, pp. 913920.

[22]. Strahler, A.N (1964), Quantitative geomorphology of drainage basins and channel networks. In: V.T. Chow (ed), Handbook of Applied Hydrology. McGraw Hill Book Company, New York, Section 4II.

[23]. Strahler, A.N. (1968). Quantitative geomorphology In: Fairbridge, R.W. (eds), 
The Encyclopedia of geomorphology, Reinhold Book Crop, New York.

\section{Nomenclature}

$\begin{array}{ll}A & \text { Area of the watershed } \\ \mathrm{B}_{\mathrm{s}} & \text { Shape factor } \\ \mathrm{C} & \text { Constant of channel maintenance } \\ \mathrm{C}_{\mathrm{c}} & \text { Compactness coefficient } \\ \mathrm{D}_{\mathrm{d}} & \text { Drainage density } \\ \mathrm{DEM} & \text { Digital elevation model } \\ \mathrm{F}_{\mathrm{s}} & \text { Stream frequency } \\ \mathrm{GIS} & \text { Geographical information system } \\ \mathrm{H} & \text { Total relief of the watershed } \\ \mathrm{I}_{\mathrm{f}} & \text { Infiltration number } \\ \mathrm{L}_{b} & \text { Basin length } \\ \mathrm{L}_{\mathrm{g}} & \text { Length of overland flow } \\ \mathrm{L}_{\mathrm{u}} & \text { Stream length. } \\ \mathrm{L}_{u m} & \text { Mean stream length } \\ \mathrm{L}_{u r m} & \text { Stream length ratio } \\ \mathrm{N}_{\mathrm{u}} & \text { Stream number } \\ \mathrm{NRSC} & \text { National Remote Sensing Center } \\ \mathrm{P} & \text { Perimeter of the watershed } \\ \mathrm{R}_{b} & \text { Bifurcation ratio } \\ \mathrm{R}_{b m} & \text { Mean bifurcation ratio } \\ \mathrm{R}_{\mathrm{c}} & \text { Circularity ratio } \\ \mathrm{R}_{\mathrm{e}} & \text { Elongation ratio } \\ \mathrm{R}_{\mathrm{f}} & \text { Form Factor } \\ \mathrm{R}_{h l} & \text { Relief ratio } \\ \mathrm{R}_{n} & \text { Ruggedness number } \\ \mathrm{R}_{\mathrm{t}} & \text { Drainage texture } \\ \mathrm{u} & \text { Stream order } \\ \mathrm{Z} & \text { Height of the basin mouth } \\ \mathrm{Z} & \text { Maximum height of the basin } \\ & \end{array}$

